\title{
Morphometric characteristics of sheep and goat fed silage comprising of cassava peel, gamba grass and Mexican sunflower
}

\author{
Ayoola J. Shoyombo', Mustapha A. Popoola ${ }^{2}$, Ake A. Moses', Olayinka O. Alabi', Ekemini M. \\ Okon ${ }^{1 *}$, Ahmed E. Jubril ${ }^{3}$ and Comfort I. Ukim ${ }^{2}$
}

\author{
${ }^{1}$ Department of Animal Science, College of Agricultural Sciences, Landmark University, P.M.B. 1001 Omu-Aran, Kwara \\ State, Nigeria. \\ ${ }^{2}$ Research and Development, Office of the Executive Secretary, TETFUND, Abuja, Nigeria. \\ ${ }^{3}$ Department of Animal Science, University of Abuja, Abuja, Nigeria.
}

*Corresponding author. Email: okon.ekeminimoses@gmail.com

Copyright (C) 2021 Shoyombo et al. This article remains permanently open access under the terms of the Creative Commons Attribution License 4.0, which permits unrestricted use, distribution, and reproduction in any medium, provided the original work is properly cited.

Received 22nd November, 2021; Accepted 23rd December, 2021

\begin{abstract}
The constant demand for less expensive and more easily available alternative feed sources for animal production is on the increase. This is particularly true in the tropics, where feed availability varies according to the season. Based on this necessity, this study aims to evaluate the impact of feeding silage to sheep and goats on growth and development. A total of 22 animals comprising of 11 Yankassa breed and 11 West African Dwarf breed were used for the study. The animals were confined and allowed to acclimatize to the environment for about 14 to 21 days, followed by 5 weeks of study. The forage used for silage was Gamba grass (Andropogon gayanus) and Mexican sunflower (Tithonia diversifolia) mixed with equal amounts of cassava peel and molasses in different proportions for three different treatments. Body length, neck circumference, height at withers, heart girth, and body weight were significantly higher $(p<0.05)$ in animals fed $T_{3}$ diets compared to all other diets, while animals on the $T_{2}$ diet had higher ear length than $T_{3}$. Except for neck circumference, ear length, and bodyweight of animals raised on diet $\mathrm{T}_{1}$ and the control group were statistically similar, all the test groups were significantly better than the control group in terms of performance. The highest body weight of $16.74 \mathrm{~kg}$ was recorded in $\mathrm{T}_{3}$, followed by $15.97 \mathrm{~kg}$ in $\mathrm{T}_{2}, 12.12 \mathrm{~kg}$ in $\mathrm{T}_{1}$, and the least value of $10.09 \mathrm{~kg}$ in the control group. No apparent adverse effects were noted in the feeding of silage to the animals as the animals were healthy throughout the duration of the study. More research on the use of silage in feeding indigenous goat and sheep breeds is needed to further understand the impact of silage on animal performance and morphometric traits.
\end{abstract}

Keywords: Alternative feed, gamba grass, Mexican sunflower, morphometric characteristics, silage, small ruminant.

\section{INTRODUCTION}

Small ruminant production plays a significant role in the supply of essential nutrients to humans, particularly in developing countries (Thornton et al., 2009; Mottet and Tempio, 2017). In Nigeria, the domestic ruminant population (estimated to be about 22.0 million sheep, 34.5 million goats, equine, and camels, and 13.9 million cattle) is regarded as under exploited (RIM, 1992; FAO, 2021). These values have increased over the years to 43.4 million sheep, 76 million goats, and 18.4 million cattle (LawalAdebowale, 2012). Such several livestock populations require a steady, reliable, and adequate supply of feed. Feed materials such as forages remain one of the primary factors that determine the success of livestock production. In Sub-Saharan Africa, inadequate feeding has long been a productivity constraint to livestock development. Thus, low birth weights, poor growth, and development, high 
infant mortality, etc. are all consequences of inadequate livestock nutrition across different environments (Lanyasunya et al., 2005; Adegoke and Abioye, 2016).

Sheep and goats cannot only survive in a variety of environments but also eat low-quality feed (Aziz, 2010; Abedo et al., 2013; Nair et al., 2021). Ruminant livestock feed in tropical areas is often made up of low-quality grasses and natural pastures, which are often scarce during the dry season. As a result, saved forages can be made available all year. Thus, feeding ruminants with preserved forages has become a common feeding approach. Forages provide between 40 and $90 \%$ of ruminant feed requirements in most ruminant production systems. Farmers who want to conserve forage on a wide scale have just two options: haymaking (which is still crucial in dry climates) and ensiling.

Forage conservation is one way to ensure that ruminant feed is available at all times by ensuring the viability of ruminant animals throughout the critical dry season (Aina, 2012). Although the nutritional characteristics of stored feed differ from those of fresh materials, sufficient quantities of nutrients are kept in preserved feed to justify its usage throughout the dry season (McCullough, 1988). Hence, ensiling provides a lot of advantages over haymaking. Large amounts of fodder can be kept in a short period, forage conservation is less weather dependent, and silage is ideally suited to mechanization. The feeding value of the resulting fodder, however, is lower than that of the original crop, which is a key disadvantage of silage production.

To date, silage research has focused on closing the feeding value gap between the original crop and the generating silage. In this case, the feeding value is the product of the likely voluntary intake and the nutritional value of the forage (Wheeler and Corbett, 1989). Silage is a type of animal feed prepared from crop wastes, forages, industrial or agricultural by-products already stored by artificial or natural acidity for animal use as feed during the period of scarce supplies. Farmers employed ensilation, which is a natural process, in ancient times. Compared with maize and grasses, legumes have a higher buffering capacity. Thus, wilting the material to between 30 and $50 \%$ dry matter (DM) before ensiling diminishes the buffering capacity, and minimizes the likelihood of butyric acid bacteria spoiling the silage (Dewhurst et al., 2003). An advantage of this is therefore an increase in feed availability which animals can utilize for growth.

Animal live body weight is a vital characteristic, although it is rarely assessed in rural regions due to a lack of sufficient skilled personnel and accurate scales. As a result, livestock producers mostly depend on unreliable estimates of their animal's body weights, resulting in diverse errors in decision-making. The fundamental way of weighing animals without a scale is to regress bodyweight to easily measure body parameters (Mayaka et al., 1995 as cited in Younas et al., 2013). Some authors have utilized body measurements to estimate body weight in a variety of sheep breeds (Sowande and Sobola, 2007; lqbal, 2010). This approach makes it easier for body measurement in different livestock species during production.

The ongoing need for cheaper and readily available alternative feed resources is paramount. This is especially true in the tropics where forage availability is seasondependent. With this necessity, this study aims to evaluate the impact of feeding silage to sheep and goats on growth and development. Specifically, the study aims to; (i) determine the impact of feeding silage on the growth of goats and sheep; (ii) evaluate the impact of silage nutrition on body morphometry; (iii) analyze the association between body weight and body measures.

\section{MATERIALS AND METHOD}

\section{Location of the experiment}

The study was conducted at Landmark University Teaching and Research Farm, Omu-Aran, Kwara State, Nigeria. Omu-Aran is located on a hill. The climatic conditions vary between dry and wet, which are referred to as harmattan and rainy, respectively. The harmattan (dry) season usually lasts five months (November to March. The wet (rainy season) typically lasts seven months (April to October, peaks in June) with 1100 to $1500 \mathrm{~mm}$ of rainfall. Annual daily average air temperatures range from 26 to $28^{\circ} \mathrm{C}$ and yearly variations of \pm 10 to $20^{\circ} \mathrm{C}$. The humidity level varies from $50 \%$ in the dry season to around $85 \%$ in the wet season.

\section{Experimental animals and management}

A total of 22 animals comprising of 11 Yankassa breed and 11 West African Dwarf breed were used for the study. The animals were confined and allowed to acclimatize to the environment for about 14 to 21 days, followed by 5 weeks of study. Before the commencement of the experiment, the animals were vaccinated and medicated following the normal routine vaccination and medication regime. The house in which they were kept was divided into partitions and each animal was placed into a cage. The animals were carefully tagged and placed according to specified treatment to give three replicate (animals) per treatment and three control animals.

\section{Experimental design}

A completely randomized design was used with 3 treatments and 1 control. The animals were placed into three treatments with three replicates (comprising of three animals each) and three animals as control. 


\section{Experimental diet}

The forage used for silage was Gamba grass (Andropogon gayanus) and Mexican sunflower (Tithonia diversifolia) mixed with equal amounts of cassava peel and molasses in different proportions for three different treatments. The diet was fed to the animals at $5 \%$ of their body weight after ensiling. An equal quantity of concentrate $(\mathrm{kg})$ was given to all animals in each replicate.

\section{Silage preparation}

Gamba grass (Andropogon gayanus) and Mexican sunflower (Tithonia diversifolia) were collected in OmuAran. The two types of forage were cut into precise smaller pieces with the use of a chopper and spread in the open where they wilted for a day. The wilted chopped forages were separated and weighed in varying amounts into 3 different air-tight tanks for 3 different treatments. The wilted chopped forages were then mixed with cassava peels and molasses (the amount of cassava peels and molasses was constant for the 3 treatments). The molasses added functioned to stimulate fermentation and facilitate natural silage preservation, increase lactic acid production, increase the intake and palatability of the forage materials, and also as a rich source of natural sugar and energy. The forages were mixed with cassava peel and molasses to make up the treatment in each airtight tank in the following proportion:

$\mathrm{T}_{1}(60 \%$ Gamba grass $+40 \%$ Cassava peel $+1 \%$ Molasses).

$\mathrm{T}_{2}(60 \%$ Mexican sunflower $+40 \%$ Cassava peel $+1 \%$ Molasses).

$\mathrm{T}_{3}$ (30\% Gamba grass $+30 \%$ Mexican sunflower $+40 \%$ Cassava peel $+1 \%$ Molasses)

Control animals were fed hay supplemented with concentrate.

\section{Data collection}

\section{Metric variables}

The weights of the animals were measured with a hanging scale, and the morphometric data was collected by measuring their bodies with a measuring tape. Animals were compelled to stand upright and two assistants confined the animals in such a way that their chests, necks, and heads, were virtually in a straight-line during body measurements. The measurements were collected once a week for 5 weeks, at least three times each, and the mean was reported to the closest centimeter.

\section{Morphometric measurements}

This study used the reference marks employed by Searle et al. (1989 a, b), Herrera et al. (1996), Salako et al. (2002), and Riva et al. (2004) for body measurement as highlighted below:

Body weight (BW): This was measured by placing each animal into a sack and putting them on a hanging scale where readings are taken.

Wither height (WH): This was measured from the ridge between the shoulder bones to the forehoof. Measurement was taken vertically from the ground to the point of withers.

Body length (BL): This was measured as the distance between the points of shoulder and hip, or the distance between the first thoracic vertebrae and the base of the tail.

Tail length (TL): This measurement was taken from the base of the tail to the tip of the tail.

Neck circumference (NC): This was measured as the circumference of the neck at the midpoint.

Heart girth (HG): This was measured as the circumference of the body at its narrowest point, just below the shoulder. Measurement was taken perpendicular to the circumference of the body, immediately in front of the hind leg, and measured perpendicular to the body axis.

Paunch girth (PG): This was measured as the circumference of the pouch just before the hind limbs.

Ear length (EL): This was measured as the distance between the ear's base and the Zygomatic arch.

\section{Statistical analysis}

The effect of the different treatments on body weight and linear measurement was estimated using the GLM procedure of the statistical analysis software (SAS, 1990) package. Means were separated using Duncan multiple range test. A stepwise regression procedure was used to find the best linear combination of metric variables that best explains the live weight. This was performed for each breed following linear multiple regression models using the SASREG procedure of the SAS (1990) package.

\section{RESULTS}

\section{Mean comparison between test groups}

Table 1 shows the impact of the feeding of silage to sheep for the duration of the study on growth and morphometric measurements. $T_{1}$ indicated animals fed silage made up of $(60 \%$ Gamba grass $+40 \%$ Cassava peel $+1 \%$ molasses) while $\mathrm{T}_{2}$ was made up of $(60 \%$ Mexican 
Table 1. Means comparison of body weight and linear measures in sheep.

\begin{tabular}{|c|c|c|c|c|c|c|}
\hline \multirow[b]{2}{*}{ Parameters } & \multicolumn{4}{|c|}{ Treatments } & \multirow[b]{2}{*}{ LOS } & \multirow{2}{*}{ SEM } \\
\hline & T1 & T2 & T3 & CTRL & & \\
\hline Body length (cm) & $51.83^{a}$ & $52.86^{\mathrm{a}}$ & $54.00^{a}$ & $51.16^{b}$ & * & 1.30 \\
\hline Neck circumference $(\mathrm{cm})$ & $27.20^{\mathrm{b}}$ & $30.69^{a}$ & $30.71^{a}$ & $26.03^{b}$ & $* * *$ & 1.04 \\
\hline Ear length $(\mathrm{cm})$ & $11.38^{b c}$ & $13.14^{\mathrm{a}}$ & $12.12^{b}$ & $11.25^{c}$ & $* \star *$ & 0.40 \\
\hline Withers height $(\mathrm{cm})$ & $58.45^{a}$ & $56.17^{b}$ & $59.21^{a}$ & $54.89^{b}$ & $\star *$ & 1.31 \\
\hline Heart girth $(\mathrm{cm})$ & $58.98^{\mathrm{b}}$ & $65.07^{a}$ & $66.01^{a}$ & $56.13^{c}$ & $* \star *$ & 1.27 \\
\hline Paunch girth $(\mathrm{cm})$ & $62.59^{\mathrm{b}}$ & $69.99^{a}$ & $69.77^{a}$ & $59.15^{c}$ & $* * *$ & 1.59 \\
\hline Tail length (cm) & $28.57^{a}$ & $28.63^{a}$ & $28.54^{a}$ & $26.50^{\mathrm{b}}$ & ** & 0.87 \\
\hline Body weight $(\mathrm{Kg})$ & $12.12^{\mathrm{b}}$ & $15.97^{\mathrm{a}}$ & $16.74^{\mathrm{a}}$ & $10.09^{b}$ & $\star \star * *$ & 1.03 \\
\hline
\end{tabular}

${ }^{a b c}$ superscript across rows indicates significant $\left({ }^{*} p<0.05 ; 0.01 ; 0.0001\right)$ differences across treatment group.

Table 2. Means comparison of body weight and linear measures in goats

\begin{tabular}{|c|c|c|c|c|c|c|}
\hline \multirow{2}{*}{ Parameters } & \multicolumn{4}{|c|}{ Treatments } & \multirow{2}{*}{ LOS } & \multirow{2}{*}{ SEM } \\
\hline & T1 & T2 & T3 & CTRL & & \\
\hline Body length $(\mathrm{cm})$ & $36.17^{d}$ & $41.60^{\mathrm{b}}$ & $44.99^{a}$ & $37.58^{c}$ & $\star \star \star *$ & 1.05 \\
\hline Neck circumference $(\mathrm{cm})$ & $21.28^{b}$ & $24.02^{\mathrm{a}}$ & $24.53^{a}$ & $19.86^{b}$ & $* * *$ & 0.94 \\
\hline Ear length $(\mathrm{cm})$ & $8.05^{b}$ & $9.19^{a}$ & $9.44^{a}$ & $8.23^{b}$ & $* *$ & 0.53 \\
\hline Withers height (cm) & $35.60^{c}$ & $40.45^{b}$ & $43.32^{a}$ & $36.93^{c}$ & $* \star *$ & 1.44 \\
\hline Heart girth $(\mathrm{cm})$ & $44.51^{\mathrm{b}}$ & $51.52^{\mathrm{a}}$ & $54.43^{\mathrm{a}}$ & $46.80^{\mathrm{b}}$ & $* \star *$ & 1.49 \\
\hline Paunch girth (cm) & $48.46^{b}$ & $57.32^{\mathrm{a}}$ & $59.22^{a}$ & $50.94^{\mathrm{b}}$ & $* * *$ & 1.54 \\
\hline Tail length (cm) & 9.57 & 10.23 & 9.77 & 9.62 & NS & 0.69 \\
\hline Body weight $(\mathrm{Kg})$ & $5.53^{\mathrm{b}}$ & $10.29^{a}$ & $11.05^{\mathrm{a}}$ & $5.64^{b}$ & $\star \star \star *$ & 0.43 \\
\hline
\end{tabular}

abc superscript across rows indicates significant $\left({ }^{*} \mathrm{p}<0.05 ; 0.01 ; 0.0001\right)$ differences across treatment group.

sunflower $+40 \%$ Cassava peel $+1 \%$ Molasses $)$ and $\mathrm{T}_{3}$ consisted of $(30 \%$ Gamba grass $+30 \%$ Mexican sunflower $+40 \%$ Cassava peel $+1 \%$ Molasses). Control animals were fed Hay supplemented with concentrate.

Measured variables ranged from 51.16 to $54.00 \mathrm{~cm}$ for body length; 26.03 to $30.71 \mathrm{~cm}$ in neck circumference; 11.25 to 13.14 in ear length; 54.89 to $59.21 \mathrm{~cm}$ in withers height; 56.13 to $66.01 \mathrm{~cm}$ in heart girth; 59.15 to $69.99 \mathrm{~cm}$ in paunch girth; 26.50 to $28.63 \mathrm{~cm}$ in tail length and 10.09 to $16.74 \mathrm{Kg}$ in body weight.

In Table 1, all measured variables showed significant $(p<0.05)$ variation across treatments. Body length, neck circumference, height at withers, heart girth, and body weight were significantly higher $(p<0.05)$ in animals fed $T_{3}$ diets compared to all other diets, while animals on the $T_{2}$ diet had higher ear length than $T_{3}$. Except for neck circumference, ear length, and bodyweight of animals raised on diet $T_{1}$ and the control group were statistically similar, all the test groups were significantly better than the control group in terms of performance. The highest body weight of $16.74 \mathrm{~kg}$ was recorded in $\mathrm{T}_{3}$, followed by 15.97 $\mathrm{kg}$ in $\mathrm{T}_{2}, 12.12 \mathrm{k} \mathrm{g}$ in $\mathrm{T}_{1}$, and the least value of $10.09 \mathrm{~kg}$ in the control group.

Table 2 shows the performance of goats fed the test diets $T_{1}, T_{2}$, and $T_{3}$ and the control group. Measured variables ranged from 36.17 to $44.99 \mathrm{~cm}$ for body length; 19.86 to $24.53 \mathrm{~cm}$ in neck circumference; 8.05 to $9.44 \mathrm{~cm}$ in ear length; 35.60 to $43.32 \mathrm{~cm}$ in withers height; 44.51 to $54.43 \mathrm{~cm}$ in heart girth; 48.46 to $59.22 \mathrm{~cm}$ in paunch girth; 9.57 to $10.23 \mathrm{~cm}$ in tail length and 5.53 to $11.05 \mathrm{Kg}$ in body weight.

All measured variables showed significant $(p<0.05)$ differences across groups except for the statistically similar tail length $(p>0.05)$ across the group. Animals on the $T_{3}$ diet were significantly superior to both $T_{1}$ and control diet while being superior to $T_{2}$ in body length and withers height alone. There existed a high disparity in body weight with $T_{2}$ and $T_{3}$ having values of 10.29 and $11.05 \mathrm{~kg}$ respectively compared to 5.53 and $5.64 \mathrm{~kg}$ obtained for $T_{1}$ and control diet.

\section{Correlated analysis between body weight and morphometric measures}

Table 3 presents the Pearson's correlation coefficient for the measured variables in sheep fed on the test and control diets. Correlation coefficients ranged from 0.07 between body length and ear length to 0.97 between paunch girth and heart girth all in the positive direction. Highly significant $(p<0.05 ; 0.01 ; 0.0001)$ correlation existed among all measured variables except for the association between ear length, withers height, tail length, and body length, ear length and neck circumference, 
Table 3. Pearson Correlation Coefficients of body weight and linear measures in sheep.

\begin{tabular}{|c|c|c|c|c|c|c|c|c|}
\hline & $\begin{array}{l}\text { Body } \\
\text { length }\end{array}$ & $\begin{array}{c}\text { Neck } \\
\text { circumference }\end{array}$ & $\begin{array}{c}\text { Ear } \\
\text { length }\end{array}$ & $\begin{array}{c}\text { Withers } \\
\text { height }\end{array}$ & $\begin{array}{l}\text { Heart } \\
\text { girth }\end{array}$ & $\begin{array}{l}\text { Paunch } \\
\text { girth }\end{array}$ & $\begin{array}{c}\text { Tail } \\
\text { length }\end{array}$ & $\begin{array}{c}\text { Body } \\
\text { weight }\end{array}$ \\
\hline \multicolumn{9}{|l|}{ Body length } \\
\hline Neck circumference & $0.56^{* * *}$ & & & & & & & \\
\hline Ear length & $0.07 \mathrm{~ns}$ & $0.04 \mathrm{~ns}$ & & & & & & \\
\hline Withers height & $0.20 \mathrm{~ns}$ & $0.28^{*}$ & $0.02 \mathrm{~ns}$ & & & & & \\
\hline Heart girth & $0.59^{* \star *}$ & $0.78^{\star \star \star}$ & $0.33^{* *}$ & $0.33^{* *}$ & & & & \\
\hline Paunch girth & $0.58^{\star * *}$ & $0.81^{* * *}$ & $0.28^{*}$ & $0.31^{*}$ & $0.97^{* \star *}$ & & & \\
\hline Tail length & $0.13 \mathrm{~ns}$ & $0.22 \mathrm{~ns}$ & $0.16 \mathrm{~ns}$ & $0.53^{* * *}$ & $0.52^{* * *}$ & $0.48^{* *}$ & & \\
\hline Bodyweight & $0.68^{\star \star \star}$ & $0.87^{\star * *}$ & $0.28^{*}$ & $0.29^{\star}$ & $0.91^{* \star *}$ & $0.89^{* * *}$ & $0.37^{* *}$ & \\
\hline
\end{tabular}

${ }^{*}$ Significant at $(p<0.05),{ }^{* *}(p<0.01),{ }^{* *}(p<0.0001) ; n s:(p>0.05)$.

Table 4. Pearson Correlation Coefficients of body weight and linear measures in goats.

\begin{tabular}{|c|c|c|c|c|c|c|c|c|}
\hline & $\begin{array}{l}\text { Body } \\
\text { length }\end{array}$ & $\begin{array}{c}\text { Neck } \\
\text { circumference }\end{array}$ & $\begin{array}{c}\text { Ear } \\
\text { length }\end{array}$ & $\begin{array}{c}\text { Withers } \\
\text { height }\end{array}$ & $\begin{array}{l}\text { Heart } \\
\text { girth }\end{array}$ & $\begin{array}{l}\text { Paunch } \\
\text { girth }\end{array}$ & $\begin{array}{c}\text { Tail } \\
\text { length }\end{array}$ & $\begin{array}{c}\text { Body } \\
\text { weight }\end{array}$ \\
\hline \multicolumn{9}{|l|}{ Body length } \\
\hline Neck circumference & $0.75^{\star \star \star}$ & & & & & & & \\
\hline Ear length & $0.70^{\star * \star}$ & $0.83^{\star \star *}$ & & & & & & \\
\hline Withers height & $0.84^{* * *}$ & $0.74^{* * *}$ & $0.71^{* * *}$ & & & & & \\
\hline Heart girth & $0.91^{* * *}$ & $0.71^{\star \star \star}$ & $0.59^{\star \star *}$ & $0.79^{\star * *}$ & & & & \\
\hline Paunch girth & $0.87^{\star \star *}$ & $0.68^{\star \star *}$ & $0.53^{\star \star \star}$ & $0.86^{* \star *}$ & $0.91^{* * *}$ & & & \\
\hline Tail length & $0.08 \mathrm{~ns}$ & $0.24 \mathrm{~ns}$ & $0.08 \mathrm{~ns}$ & $0.34^{*}$ & $0.35^{\star *}$ & $0.37^{* *}$ & & \\
\hline Bodyweight & $0.80^{\star \star *}$ & $0.76^{\star \star \star}$ & $0.57^{\star * *}$ & $0.70^{\star * *}$ & $0.78^{\star * \star}$ & $0.82^{* * *}$ & $0.23 \mathrm{~ns}$ & \\
\hline
\end{tabular}

${ }^{\star}$ Significant at $(p<0.05),{ }^{* \star}(p<0.01),{ }^{* \star *}(p<0.0001) ; n s:(p>0.05)$.

Table 5. Stepwise linear regression analysis of morphometric measures that impact body weight.

\begin{tabular}{llll}
\hline Animals & Equation & ${\text { Adjusted } \mathrm{R}^{2}}$ & LOS \\
\hline Sheep & $\mathrm{Y}=-11.46+5.24 \mathrm{HG}+5.48 \mathrm{NC}+3.20 \mathrm{BL}+2.01 \mathrm{EL}$ & 0.899 & ${ }^{* * *}$ \\
Goat & $\mathrm{Y}=-8.088+0.573 \mathrm{PG}+0.37 \mathrm{NC}$ & 0.744 & ${ }^{* * *}$ \\
\hline
\end{tabular}

${ }^{* * *}(p<0.0001)$; HG: heart girth; NC: neck circumference, BL: body length, EL: ear length; PG: paunch girths.

withers height, and tail length. Also, tail length displayed an insignificant $(p>0.05)$ association with body length, neck circumference, and ear length respectively. There was also a highly significant association between body weight and all other linear body measures.

Table 4 presents the Pearson's correlation coefficient for the measured variables in goats fed on the test and control diets. Correlation coefficients ranged from 0.08 between body length and tail length to 0.91 among paunch girth, heart girth, and body length all in the positive direction.

Highly significant $(p<0.05 ; 0.01 ; 0.0001)$ correlation existed among all measured variables except for tail length which displayed insignificant $(p>0.05)$ association with body length, neck circumference, and ear length and body weight respectively. There was a highly significant association between body weight and all other linear body measures except for the association with the tail length which was non-significant.

\section{Stepwise linear regression analysis of morphometric measures that impact on body weight}

Table 5 presents the stepwise linear regression analysis results for sheep and goats raised on test diets. Of all measures, variables regressed on body weight, only heart girth, neck circumference, body length, and ear length were entered into the equation with a high level of significance $(p<0.0001)$ and an R-value of 0.899 in the sheep fed the diets used in this study, while in the goats, only paunch girth and neck circumference were entered with a similar level of significance and R-value of 0.744 . 


\section{DISCUSSIONS}

\section{Mean performance of animals fed test diet and control}

The observed significant differences between the sheep and goat fed silage free diet (the control group) and those fed various types of silage diet in body weight and morphometric measures agreed with the findings of Anaeto et al. (2013) who reported similar observations when feeding cassava silage to West African Dwarf (WAD) sheep. Also, the trend of increasing body weight with increasing level of silage in the diet was consistent with the report of Khaing et al. (2015) on the digestibility and growth performance of goats fed Napier grass and whole corn plant silage. This increasing trend in body weight might be due to increased Dry Matter Intake (DMI), high energy in the silage, and high content of digestible nutrients than hay and concentrate fed the control animals. Browne (2000), on the other hand, stated that the addition of a large amount of corn silage to the grass silage basal diet had a negative effect on voluntary intake and growth performance due to the accumulation of a high level of fermentation acid, which may have suppressed the activity of cellulolytic bacteria in the rumen.

However, differences in obtained measures could be attributed to differences in breeds of animals used, age, and climatic conditions. Salam (2009) stated that diets with a high energy content, which is more common in silage than hay/concentrate mix, will aid in increasing the microbial protein synthesis level by synchronizing available ammonia nitrogen and energy in the rumen, resulting in improved nutrient digestibility and BW gained. Furthermore, rumen microbes may have digested a high quantity of lactic acid in silage into propionic acid (Abedo et al., 2013). Propionic acid is taken into the bloodstream through the rumen wall and subsequently converted to glucose in the liver. The animal will utilize the glucose produced as an energy source for body needs (Hariadi and Santoso, 2010).

The apparent poor performance of goats fed diet $1(60 \%$ Gamba grass $+40 \%$ Cassava peel $+1 \%$ molasses) compared to the other 2 silage classes and the control may be due to the initial off-taste of the silage mix and because the goats are picky which may lead to poor growth at the initial period of adjustment. It could also be explained that the constituent of the silage which is Gamba grass and Cassava had lower protein value compared to Mexican sunflower that would be more nutritious.

\section{Correlated analysis between body weight and morphometric measures}

This analysis was carried out to determine if there were any adverse impacts of silage feeding on linear body development. Observed significant correlations between linear body measures and body weight in this study for both animals are consistent with the reports of several authors (Abdel-Moneim, 2009, Cam et al., 2010; Iqbal, 2010) who all variously reported positive and highly significant correlation between body weight and various linear measures except for few cases.

Because body weight and body measures have a high correlation coefficient, either of these factors or a combination of them could provide a solid estimate for forecasting live weight in sheep and goats. Paunch girth and heart girth had the strongest connection with body weight in almost all cases. Thiruvenkadan (2005) hypothesized that the stronger link between body weight and chest girth was owing to the chest girth's comparatively larger contribution to body weight (consisting of bones, muscles, and viscera).

The overall importance of this is that the high association points to the fact that body weight was not just due to fat deposition or visceral mass but adequate body development of animals raised on silage as dry season resource feed. Also, skeletal measurements like ulna length, body height and length, and chest depth are less altered by nutrition and hence better reflect natural size than dimensions related to fat and muscle deposition, like breadth and girth measurements and body weights (Semakula et al., 2010). In females, gut-fill and pregnancy have an impact on parameters relating to fat and muscle deposition. In beef cattle, the diet has a greater impact on length than on height (Semakula et al., 2010). The restricted diet reduced the growth of height and body length in cattle during the growing period, according to Coleman and Evans (1985) as quoted in Semakula et al. (2010).

\section{Stepwise linear regression analysis of morphometric measures that impact on body weight}

Observed high coefficient of determination $R^{2}$ value $(0.899$ and 0.744 ) obtained for both sheep and goat respectively were similar with the values reported by Rani et al. (2010) in matured goats for pooled, individual gender, and twin analysis. Multiple body measurements were included in regression equations with the highest $R^{2}$ values in this study and suggest a more accurate estimation by the combination of two or more measurements. This agrees with the findings of Bassano et al. (2003) and Thiruvenkadan (2005).

\section{Conclusion}

It was observed that significant differences in mean body weight and morphometric measurements existed across treatment groups with animals fed on silage performing better than control animals in almost all cases for both sheep and goats. However, bodyweight was positively and significantly correlated with all linear body measurements 
in most cases. Pouch girth, neck circumference, and heart girth in combination with two or more measurements predicted the body weight better. No apparent adverse effects were noted in the feeding of silage to the animals as the animals were healthy throughout the duration of the study. Therefore, further studies on the use of silage in feeding indigenous breeds of goats and sheep are essential to further understand its impact on animal performance and morphometric characteristics.

\section{DECLARATIONS OF INTEREST}

The authors declare no conflict of interest.

\section{REFERENCES}

Abdel-Moneim, A. Y. (2009). Use of live body measurements for prediction of body and carcass cuts weights in three Egyptian breeds of sheep. Egyptian Journal of Sheep and Goat Sciences, 4(2), 17-32.

Abedo, A. A., Hafez, Y. H., Khalifa, E. I., Mohamed, B., \& ElZolaky, O. A. (2013). Milk yield and composition of dairy Zaraibi goats fed microbial inoculated corn silage. Egyptian Journal of Sheep and Goat Science 8(1), 141-151.

Adegoke, A. T., \& Abioye, A. A. (2016). Improving livestock productivity: Assessment of feed resources and livestock management practices in Sudan-Savanna zones of West Africa. African Journal of Agricultural Research, 11(5), 422440.

Aina A. B. J. (2012). Goat (Capra hircus): A misunderstood animal. 35th Inaugural Lecture 2012, Federal University of Agriculture Abeokuta, Nigeria. 28th March, 2012.

Anaeto, M., Sawyerr, A. F., Alli, T. R., Tayo, G. O., Adeyeye, J. A., \& Olarinmoye, A. O. (2013). Cassava leaf silage and cassava peel as dry season feed for West African dwarf sheep. Global Journal of Science Frontier Research Agriculture and Veterinary Sciences, 13(2), 1-4.

Aziz, M. A. (2010). Present status of the world goat populations and their productivity. Lohmann Information, 45(2), 42-52.

Bassano, B., Bergero, D., \& Peracino, A. (2003). Accuracy of body weight prediction in Alpine ibex (Capra ibex, L. 1758) using morphometry. Laboratory Animal Science.,42(6), 589592.

Browne, E. M. (2000). Maize silage- based diets for finishing beef cattle. Ph.D. Thesis. The University of Reading, UK.

Cam, M. A., Olfaz, M., \& Soydan, E. (2010). Possibilities of using morphometrics characteristics as a tool for body weight prediction in Turkish Hair Goats (Kilkeci). Asian Journal of Animal and Veterinary Advances, 5(1), 52-59.

Coleman, S. W., \& Evans, B. C. (1986). Effect of nutrition, age and size on compensatory growth in two breeds of steers. Journal of Animal Science, 63(6), 1968-1982.

Dewhurst, R. J., Fisher, W. J., Tweed, J. K., \& Wilkins, R. J. (2003). Comparison of grass and legume silages for milk production. 1. Production responses with different levels of concentrate. Journal of Dairy Science, 86(8), 2598-2611.

Food and Agricultural Organisation of United Nations (FAO) (2021). Nigeria agriculture at a glance. Retrieved 19th November, 2021 from https://www.fao.org/nigeria/fao-in- nigeria/nigeria-at-a-glance/en/.

Hariadi, B. T., \& Santoso, B. (2010). Evaluation of tropical plants containing tannin on in vitro methanogenesis and fermentation parameters using rumen fluid. Journal of the Science of Food and Agriculture, 90(3), 456-461.

Herrera, M., Rodero, E., Gutierrez, M. J., Pena, F., \& Rodero, J. M. (1996). Application of multifactorial discriminant analysis in the morphostructural differentiation of Andalusian caprine breeds. Small Ruminant Research, 22(1), 39-47.

lqbal, Z. M. (2010). Relationship between live body weight and body measurements in Kajli sheep. M.Phil Thesis, Department of Livestock Production, University of Veterinary and Animal Sciences, Lahore.

Khaing, K. T., Loh, T. C., Ghizan, S., Halim, R. A., \& Samsudin, A. A. (2015). Feed intake, growth performance and digestibility in goats fed whole corn plant silage and Napier grass. Malaysian Journal of Animal Science, 18(1), 87-98.

Lanyasunya, T. P., Musa, H. H., Yang, Z. P., Mekki, D. M., \& Mukisira, E. A. (2005). Effects of poor nutrition on reproduction of dairy stock on smallholder farms in the tropics. Pakistan Journal of Nutrition, 4(2), 117-122.

Lawal-Adebowale, O. A. (2012). Dynamics of ruminant livestock management in the context of the Nigerian agricultural system. Livestock Production, 4, 61-79.

Mayaka, T. B., Tchoumboue, J., Manjeli, Y., \& Teguia, A. (1996). Estimation of live body weight in West African Dwarf goats from heart girth measurement. Tropical Animal Health and Production, 28(1), 126-128.

McCullough, M E. (1978). New trends in ensiling forages. In: Ruminant nutrition: Selected articles from the World Animal Review. FAO Animal Production and Health Paper 12. FAO (Food and Agriculture Organization of the United Nations), Rome, Italy. Pp. 24-29.

Mottet, A., \& Tempio, G. (2017). Global poultry production: current state and future outlook and challenges. World's Poultry Science Journal, 73(2), 245-256.

Nair, M. R., Sejian, V., Silpa, M. V., Fonsêca, V. F. C., de Melo Costa, C. C., Devaraj, C., Krishnan, G., Bagath, M., Nameer, P.O., \& Bhatta, R. (2021). Goat as the ideal climate-resilient animal model in tropical environment: revisiting advantages over other livestock species. International Journal of Biometeorology, 65(12), 2229-2240.

Rani, V. U. (2010). Efficient management of feed resources using data mining techniques (Doctoral dissertation, Christ University).

Resource Inventory and Management (RIM) (1992). Nigerian Livestock resources. Four volume report to the Federal Government of Nigeria. Submitted by Resource Inventory Management Limited. 1. Executive Summary and Atlas. 2. National synthesis. 3. State Reports. 4. Urban Reports and commercially managed livestock survey report.

Riva, J., Rizzi, R., Marelli, S., \& Cavalchini, L. G. (2004). Body measurements in Bergamasca sheep. Small Ruminant Research, 55(1-3), 221-227.

Salako, A. E., \& Ngere, L. O. (2002). Application of multifactorial discriminate analysis in the morphometric structural differentiation of West African Dwarf (WAD) and Yankassa sheep in the South West. Nigerian Journal of Animal production, 29(2), 163-167.

Salam, N. A. (2009). The effect of forage energy level on production and reproduction performance of Kosta female goats. Pakistani. Journal of Nutrition, 8(3), 251-255.

Searle, T. W., Graham, N. M., \& Donnelly, J. B. (1989a). Change of skeletal dimensions during growth in sheep: the effect of 
nutrition. The Journal of Agricultural Science, 112(3), 321-327. Searle, T. W., Graham, N. M., Donnelly, J. B., \& Margan, D. E. (1989b). Breed and sex differences in skeletal dimensions of sheep in the first year of life. The Journal of Agricultural Science, 113(3), 349-354.

Semakula, J., Mutetikka, D., Kugonza, R. D., \& Mpairwe, D. (2010). Variability in body morphometric measurements and their application in predicting live body weight of Mubende and Small East African goat breeds in Uganda. Middle East Journal of Scientific Research, 5(2), 98-105.

Sowande, O. S., \& Sobola, O. S. (2007). Body measurements of west African dwarf sheep as parameters for estimation of live weight. Tropical Animal Health and Production, 40(6), 433-439.

Thiruvenkadan A. K. (2005). Determination of best fitted regression model for estimation of body weight in Kanni Adu kids under farmer's management system. Livestock Research for Rural Development, 17(7), 103-107.
Thornton, P. K., Van de Steeg, J., Notenbaert, A., \& Herrero, M. (2009). The impacts of climate change on livestock and livestock systems in developing countries: A review of what we know and what we need to know. Agricultural System, 101(3), 113-127.

Wheeler, J. L., \& Corbett, J. L. (1989). Criteria for breeding forages of improved feeding value: results of a Delphi survey. Grass and Forage Science, 44(1), 77-83.

Younas, U., Abdullah, M., Bhatti, J. A., Pasha, T. N., Ahmad, N., Nasir, M., \& Hussain, A. (2013). Inter-relationship of body weight with linear body measurements in Hissardale sheep at different stages of life. The Journal of Animal \& Plant Sciences, 23(1), 40-44. 